\title{
Assessment of Salivary and Serum Proteins in Patients with Oral Tumors
}

\author{
Rukzan M. Dawood" \\ Received 17, September, 2012 \\ Accepted 4, December, 2012
}

Hathama R. Hasan ${ }^{* *}$

\begin{abstract}
The qualified subjects for this study included 33 patients with benign and malignant oral tumors aged 15-75 years and 31 matched age and gender healthy subjects used as control. Proteins measurements included total protein, albumin, globulines in sera and saliva samples, and immunoglobulins (IgG, IgM, IgA) in sera samples of control and patients. Meanwhile, polyacrylamide gel electrophoresis (PAGE) was used to differentiate between protein patterns in both serum and saliva samples among the studied groups. The gel was also stained for glycoprotein to evaluate as well the changes in glycoprotein contents. For total protein, the results revealed a signifigant increase $(\mathrm{P} \leq 0.01)$ in both samples (serum and saliva) of patient group. Albumin concentration shows presence of a high significant decrease $(\mathrm{P}=0.001)$ in sera samples but a significant increase $(\mathrm{P}<0.05)$ in saliva of the patients group in comparison to that of control group. Immunoglobulins concentrations also show significant increase in patients group in comparison to control group.

This study aimed to estimate salivary and serum proteins in oral cancer patients and in healthy control group to evaluate their role in diagnosis and prognosis of oral cancer
\end{abstract}

\section{Key words: Total Protein, Oral Cancer, Saliva, Immunoglobulin, Albumin}

\section{Introduction}

Systemic diseases such as cancer, cardiovascular, metabolic and neurological diseases may be diagnosed using other biological fluids than blood [1]. Blood is the most commonly used fluid for laboratory diagnostic procedures which involves the analyses of the cellular and chemical constituents. Saliva has been used in the past few decades as a new diagnostic fluid [2]. It is produced by the three major salivary glands (parotid, submandibular and sublingual) as well as by numerous minor salivary glands [3]. The salivary fluid contains water, normal proteins, post-translationally modified proteins (glycoproteins), peptides, lipids, minerals, antioxidants and other small molecules [4]. Saliva contains locally produced substances and other molecules derived from the systemic circulation, such as serum products, gingival crevicular fluid (GCF), electrolytes, microorganisms and other foreign substances [1]. Even markers for hormonal, infectious, immunological and toxicological diseases can be determined in saliva [5]. The oral cavity can be an alternative tool for monitoring the oral and systemic health. Therefore, saliva is often called the mirror of the body [2]. Detection of cancer at the early stage is of utmost importance to decrease the morbidity and mortality of the disease. And as it is known in the setting of neoplastic conditions, many biochemical substances deviate from their normal values; these may include proteins of body fluid. Noninvasive

*Department of Chemistry,College of Education for Girls, Mosul University/Iraq

${ }^{* *}$ Department of Chemistry, College of Science, Baghdad University/Iraq 
methods like analysis of saliva may provide a coast-effective approach for screening large population [2]. The knowledge of body fluid proteins and their alternations in health and disease has grown rapidly, some of the alternations have a genetic origin, and many more reflect physiological or pathological processes [6, 7]. Saliva contains proteins in concentration of approximately $3 \%$ of plasma protein level [8]. Human saliva proteins can be informative for disease detection and surveillance of oral health $[9,10]$. Measurement of total protein concentration provides general information, reflecting disease states in many organs systems, so alternation in serum total protein concentration is used commonly in clinical practice as a non-specific indicator for underlying disease or monitor disease activity $[11,12]$. Oral cancer is the $6^{\text {th }}$ most common cancer in the world, with a high morbidity rate, and a 5-years mortality rate of about $50 \%$ [13]. Delayed detection is likely to be a primary reason for the high morbidity rate of oral cancer patients, and this support the imperative need for sensitive biomarker to improve early detection of oral cancer. The aim of the present study is to estimate salivary and serum proteins concentration in oral cancer patients and in healthy control group to evaluate their role in diagnosis and prognosis of oral cancer.

\section{Materials and methods}

This study had been carried out on patients attending the hospital of Specialized Surgery in Baghdad Medical City. Patients were evaluated by full medical history to exclude any existing of systemic disease or taking any drug that may affect the parameters to be examined. Sixty four individuals were included in the present study; thirty three of them (male and female aged 15-75 years) were clinically and histologically diagnosed as patients with oral epithelial tumors (benign and malignant). Control group composed of thirty one age and gender matched healthy individuals.

Serum and saliva collection: - A volume of six milliliters of venous blood was taken from each individual, then was centrifuged at $(2000 \mathrm{xg})$ for 10 minutes. The obtained sera were transferred immediately to other test tubes and frozen at $-20{ }^{\circ} \mathrm{C}$ for subsequent analysis. Hemolyzed samples were discarded. About ten milliliters of unstimulated (resting) whole saliva were collected, under resting conditions. Patients and healthy individuals were asked to rinse their mouth with water and to generate saliva in their mouth and to spit into a wide test tube [14]. The collection time was always between 8.0-10.0 a.m., the collection period was twenty minutes. The collected saliva was centrifuged at $(2000 \mathrm{xg})$ for 10 minutes, this was done within one hour after collection to eliminate debris and cellular matter. The resulting supernatant was stored at $\quad-20$ ${ }^{\circ} \mathrm{C}$ in polyethylene tubes until assayed.

\section{Total protein determination}

Total protein (TP) concentration of all samples (serum and saliva) was determined using the modified Lowry method by Hartree [15]. Bovine serum albumin (BSA) was used as standard. Protein concentrations of serum and saliva were expressed in $\mathrm{g} / \mathrm{dl}$.

\section{Albumin determination}

Serum and saliva albumin (alb) was determined by dye-binding method [16] using kit manufactured by bioMerieux. The measurement of albumin is based on its quantitative binding at $\mathrm{pH} 4.2$ with bromocresol green (BCG) to form a blue-green complex.

\section{Globulins determination}


The concentration of the globulins in the serum \& saliva samples of healthy and oral tumor patient groups was calculated, using the following equation: $\quad \mathrm{C}_{\mathrm{glob}}(\mathrm{g} / \mathrm{dl})=\mathrm{C}_{\mathrm{TP}}-$ $\mathrm{C}_{\mathrm{alb}}$

\section{Immunoglobulin determination}

The serum immunoglobulines were determined using Radial Immuno Diffusion plates (RID) of Mancini [17], for quantitative determination of these proteins in serum and other biological fluids. This technique involves immuno precipitation in agarose, between an antigen and its homologous antibody.

\section{Conventional polyacrylamide gel electrophoresis}

In order to detect the differences in total protein and glycoprotein present in the studied groups. Conventional polyacrylamide gel electrophoresis (PAGE) was carried out according to LKB 2117 note. To detect the location of the protein bands and to identify the differences in their profile, CBB-G250 stain was used according to Neuhoff et al [18], and Schiff's reagent was used to detect the glycoprotein profile according to Leach et al [19].

\section{Statistical Analysis}

The findings were expressed as the mean \pm standard deviation. The data were analyzed with student's independent $t$ test. All statistical analyses were performed with the program Statistical Package for the Social Science (SPSS for windows, version 10.0). A $P$ value of $<0.05$ was accepted as statistically significant [20].

\section{Results and disussion}

Comprehensive analysis and identification of the proteins in sera and saliva samples is a necessary first step toward the discovery of protein change for human disease detection [11].

Table (1) Mean value of total protein in sera and saliva samples of healthy (control) and patient groups (benign and malignant)

\begin{tabular}{|l|l|l|l|l|}
\hline \multirow{2}{*}{ Group } & \multirow{2}{*}{$\begin{array}{l}\text { Samples } \\
\text { Numbers }\end{array}$} & $\begin{array}{l}\text { Age(year) } \\
(\text { Mean } \pm \text { SD) }\end{array}$ & $\begin{array}{l}\text { ( Mean } \pm \text { SD) } \\
\text { g/dl }\end{array}$ \\
\cline { 4 - 5 } & & Serum & Saliva \\
\hline $\begin{array}{l}\text { Control } \\
\text { (healthy) }\end{array}$ & 31 & $35.66 \pm 11.64$ & $7.72 \pm 1.45$ & $0.221 \pm 0.062$ \\
\hline $\begin{array}{l}\text { Benign } \\
\text { Tumor patient }\end{array}$ & 14 & $35.78 \pm 15.63$ & $8.8 \pm 2.015$ & $0.326 \pm 0.26$ \\
\hline $\begin{array}{l}\text { Malignant } \\
\text { Tumor patient }\end{array}$ & 19 & $46.57 \pm 15.21$ & $9.74 \pm 2.309^{* *}$ & $0.504 \pm 0.387^{* *}$ \\
\hline
\end{tabular}

In the current study, the total protein in sera samples of patient groups Table (1) was found to be markedly increased, when compared with that of the control group. This result is accordant with several studies referred to the presence of significant increase in $\mathrm{TP}$ concentration in patients with different types of cancer [21]. Such increase in TP concentration can be explained as follows: - the whole body of cancer patient is engaged in synthesis of variable forms of proteins, like globulins, immunoglobulin, enzymes [22] and other proteinous material. Among these proteins a 
group of several proteins called positive Acute Phase Reactants (APR). Negative acute phase reactants proteins are group of proteins in the body which were reported to decrease in concentration upon inflammation, like albumin and prealbumin[23]. The synthesis of positive (APR) proteins exceeded the synthesis of negative APR (albumin, prealbumin), such imbalance lead to a marked increase in serum total protein. Salivary total protein levels were also markedly increased Table (1) and this is in agreement with a study on brain tumors [24]. This increase may be explained on the basis that saliva in general, contains arrays of proteins that have distinct biological function, most of them have antioxidant, antibacterial, antimicrobial, and antibodies properties [25] defend the oral environment against any noxious agents, and such proteins were reported to increase in case of inflammation and tumors. Furthermore, it has been reported that many serum-derived proteins transferred to the saliva during inflammation [2].

The presence of distinct variations in the proteins and glycoprotein separation profile was observed among the studied groups, Figure (1) shows that the proteins in sera of benign and malignant tumor patient groups (Lane5, 6) was separated to 10 bands and only 7 bands were detected in sera of the (healthy) control group (Lane 8).

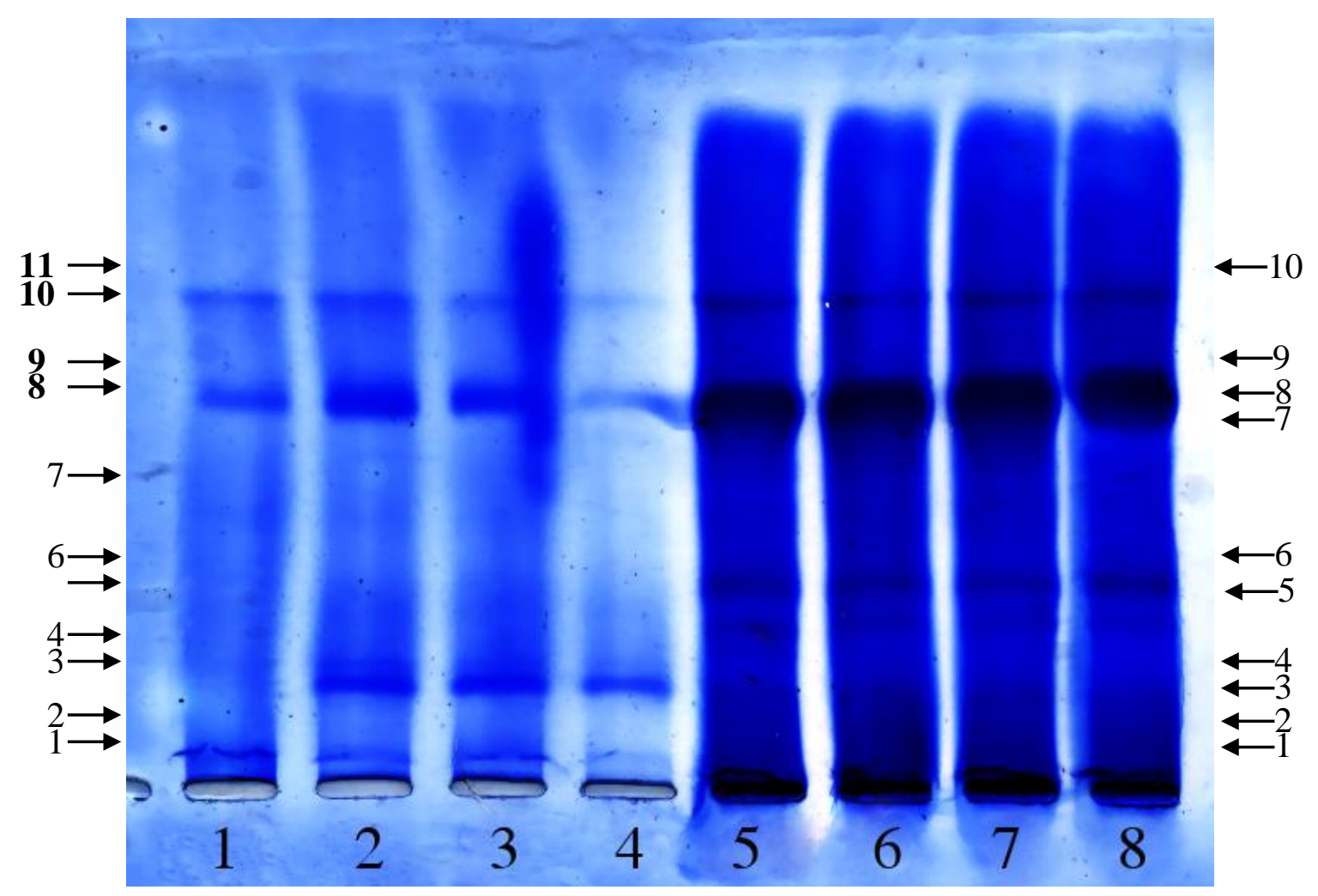

Fig (1): Conventional poly acrylamide gel electrophoresis $7.5 \%$, using tris-glycin pH 8.9 as electrode buffer. Electorophoresis was carried out for 3 hours at $4 \mathrm{C}$ using a constant current of 40 $\mathrm{mA}$ and a voltage of $15 \mathrm{~V} / \mathrm{Cm}$ the gel was stained for protein. The samples used were as follows:

1 crude saliva (individual malignant)

3 pooled crude saliva (benign)

5 crude serum (individual malignant)

7 pooled crude serum (benign)
2 pooled crude saliva (malignant)

4 pooled crude saliva (control)

6 pooled crude serum (malignant)

8 pooled crude serum (control) 
The differences were also clear among the studied groups, when the gel was stained for glycoprotein; Figure (2). The sera glycoprotein profile shows obvious differences between the studied groups, and the new bands that appeared in benign and malignant groups, most of them were concentrated in the middle part of globulin region.

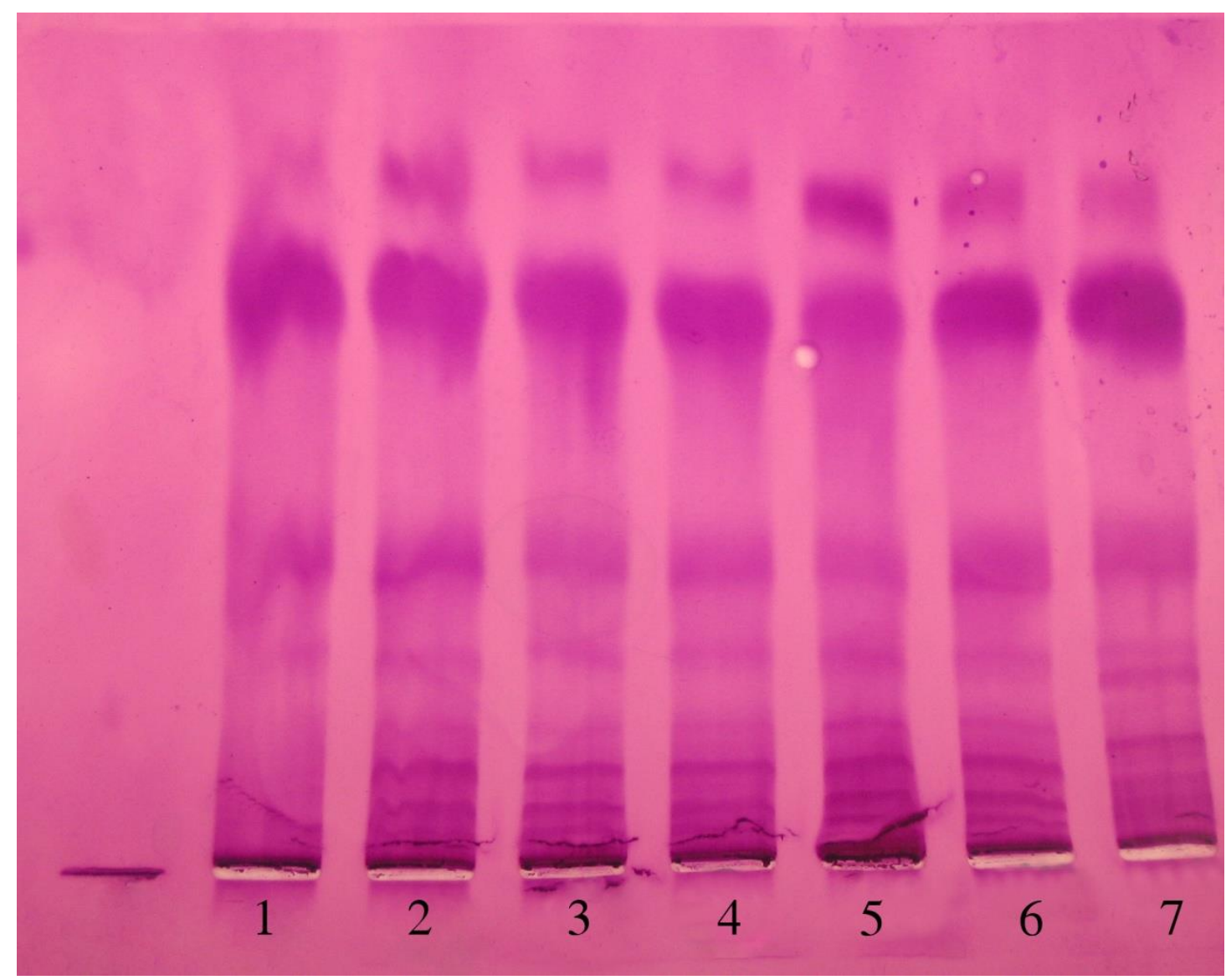

Fig (2): Conventional poly acrylamide gel electrophoresis $7.5 \%$, using Tris- glycin pH 8.9 as an electrode buffer. The gel was stained for glycoprotein using Schiff reagent.

The samples used were:

1, Crude pooled serum (control)

5, 6, 7 Crude pooled serum (malignant)

2, 3, 4 Crude pooled serum (benign)

Salivary total protein profil in Figure (1) shows distinct differences between the three studied groups, where in malignant tumor patients group (Lane 1) eleven protein bands were appeared, in comparison to only six bands detected in the healthy (control) group (Lane 4). The variations in the protein profile Figure (1) is obvious from the comparison among the sera and saliva samples of the different oral tumor groups and control group, that the protein in saliva of benign and malignant groups (Lane 2, 3) and sera of both groups (Lane 6, 7) were separated into more protein bands than those were detected in pooled saliva and sera of healthy (control) group (Lane 4) and (Lane 8) respectively. The alteration in the numbers and position of protein bands detected in sera and saliva samples of the different studied groups may reflect altered gene expression in cancer patient which leads to produce altered proteins [26]. It is clear from the electrozymogram that the protein bands detected in saliva samples were more than those 
detected in the serum samples, some of the bands migrate to the same distance in both serum and saliva samples of the studied groups. This agrees with the literature mention about that some proteins are transported from serum to saliva (serum derived proteins) whereas the others are derived from salivary glands. And the significant increase observed in this study agrees with the suggestion of leakage of serum components into the mouth (saliva) [4].

Reduction in albumin level was observed in sera of oral tumor patients as the result in table (2) shows:

Table (2) Mean value of sera and salivary albumin concentration in control and patient groups

\begin{tabular}{|l|l|l|l|l|}
\hline Group & $\begin{array}{l}\text { Samples } \\
\text { Numbers }\end{array}$ & $\begin{array}{l}\text { Age(year) } \\
\text { (Mean } \pm \text { SD) }\end{array}$ & $\begin{array}{l}\text { (Mean } \pm \text { SD) } \\
\text { g/dl }\end{array}$ & Serum \\
\hline $\begin{array}{l}\text { Control } \\
\text { (healthy) }\end{array}$ & 31 & $35.66 \pm 11.64$ & $4.49 \pm 0.72$ & $0.027 \pm 0.019$ \\
\hline $\begin{array}{l}\text { Benign } \\
\text { (Tumor patient) }\end{array}$ & 14 & $35.78 \pm 15.63$ & $3.68 \pm 0.92^{*}$ & $0.069 \pm 0.047^{*}$ \\
\hline $\begin{array}{l}\text { Malignant } \\
\text { (Tumor patient) }\end{array}$ & 19 & $46.57 \pm 15.21$ & $3.42 \pm 0.87^{* *}$ & $0.078 \pm 0.076^{*}$ \\
\hline
\end{tabular}

** Highly significant difference in comparison to control at $(\mathrm{P} \leq 0.001)$

* Significant difference in comparison to control at $(\mathrm{p}<0.05)$

Generally cancer patients have lower serum albumin concentration than the healthy individuals. Many references reported that a reduction in albumin concentration occurred in inflammatory processes, chronic inflammatory disease, and in neoplastic disease [25]. The reduction in sera albumin concentration that observed in the current study may be explained as follows: - Liver is the site for the synthesis of most proteins including both negative APR (pre albumin and albumin) and positive APR. It is well known that the concentration of positive APR in serum increased in malignancy, which means that liver will be busy with synthesis of this type of APR leaving behind the synthesis of other proteins like albumin, so the synthesis of inflammatory cytokines which increased in malignancy, such as tumor necrosis factor- $\alpha$ (TNF- $\alpha)$ and interlukines and C-reactive protein seems to cause a reduction in albumin concentration [27]. Moreover, nutritional deficiency and weight loss in association with psychological distress and lower quality of life may cause reduction in sera albumin concentration [28]. The other cause of the observed reduced albumin level in sera of patient group may be due to the role of albumin as one of the extracellular antioxidants [29] where albumin constitutes up to $49 \%$ of total plasma antioxidant status. Meanwhile albumin acts as sacrificial antioxidant by inhibiting the generation of free radicals through an immediate attacks of albumin molecule itself, so the radical reaction continue on albumin surface and cause damage to albumin molecule[29], such damage is probably biologically insignificant, due to that the albumin is present in plasma in high concentration. 
In contrast to sera albumin, throughout the present study, salivary albumin concentration showed a significant increase (Table 2) in patient groups in comparison to that of the control. This increase is in agreement with other studies on oral sequamous cell carcinoma (OSCC) patients where an increase in salivary albumin concentration was also recorded [30]. In the oral cavity, albumin in saliva was reported to be blood derived protein, and it may diffuse into the mucosal secretions, so the marked increase level of albumin may be related to the increase of tissue damage and loss of epithelial barrier function and increased vascular permeability leading to leakage or escape of many plasma proteins including albumin to extracellular spaces (interstiasial) and through cervicular fluid to saliva causing increase in salivary albumin [31]. Salivary albumin has been shown to increase in medically compromised patients whose general condition gets worse. It may be hypothesized that salivary albumin can be used to assess the integrity of mucosal function in the mouth. Albumin in the whole saliva may be a marker and predictor of stomatitis [32], since an increase in albumin concentration in whole saliva was always detected prior to the clinical appearance of stomatitis.

In the current study, globulin concentration showed a significant increase in patient groups as represent in( Table 3), and this may attribute to that: most of the positive (APR ) are globulins (i.e. glycoprotein), so the increased level of globulins is due to the increased synthesis of positive APR in malignancies. This change in globulins concentration was confirmed by the significant increase in glycoprotein bands observed upon electrophoresis (Figure 2) of benign and malignant groups when compared with that of the (healthy) control group. The additional bands that appear in glycoprotein profile, particularly in the globulins region result from the synthesis of the positive APR during inflammation.

Table (3) Mean value of sera and saliva globulin concentration in control and patient groups

\begin{tabular}{|c|c|c|c|c|}
\hline \multirow[t]{2}{*}{ Group } & \multirow{2}{*}{$\begin{array}{l}\text { Samples } \\
\text { Numbers }\end{array}$} & \multirow{2}{*}{$\begin{array}{l}\text { Age }(\text { year }) \\
(\text { Mean } \pm \text { SD) }\end{array}$} & \multicolumn{2}{|l|}{$\begin{array}{l}(\text { Mean } \pm \text { SD }) \\
\text { g/dl }\end{array}$} \\
\hline & & & Serum & Saliva \\
\hline $\begin{array}{l}\text { Control } \\
\text { (healthy) }\end{array}$ & 31 & $35.66 \pm 11.64$ & $3.23 \pm 0.74$ & $0.194 \pm 0.04$ \\
\hline $\begin{array}{l}\text { Benign } \\
\text { (Tumorpatient) }\end{array}$ & 14 & $35.78 \pm 15.63$ & $5.12 \pm 1.12^{*}$ & $0.257 \pm 0.21^{* *}$ \\
\hline $\begin{array}{l}\text { Malignant } \\
\text { (Tumor patient) }\end{array}$ & 19 & $46.57 \pm 15.21$ & $6.32 \pm 1.44^{* * *}$ & $0.426 \pm 0.311$ \\
\hline
\end{tabular}

***Highly Significant difference in comparison to control at $(\mathrm{P} \leq 0.001)$

** Significant difference in comparison to control at $(\mathrm{P}<0.01)$

*Significant difference in comparison to control at $(\mathrm{P}<0.05)$

Immunoglobulins ( $\operatorname{IgA}, \operatorname{IgG}$ and $\operatorname{IgM}$ ) concentrations were measured in sera samples of healthy individuals (control) and oral tumor patient 
groups, and Table (4) shows a significant increase in IgA and IgG .

Table (4)Mean value of sera immunoglobulin concentration in healthy(control) and patient groups

\begin{tabular}{|l|l|l|l|l|l|}
\cline { 3 - 6 } \multicolumn{2}{l|}{} & \multicolumn{2}{l|}{ Mean \pm SD mg/dl } \\
\hline Group & $\begin{array}{l}\text { Sample } \\
\text { numbers }\end{array}$ & $\begin{array}{l}\text { Age(year) } \\
\text { Mean } \pm \text { SD }\end{array}$ & IgA & IgG & IgM \\
\hline $\begin{array}{l}\text { Control } \\
\text { (healthy) }\end{array}$ & 31 & $35.66 \pm 11.64$ & $149.02 \pm 21.44$ & $1219.93 \pm 128.2$ & $174.95 \pm 72.57$ \\
\hline Benign & 14 & $35.78 \pm 15.63$ & $288.7 \pm 175.75^{* * *}$ & $1300.29 \pm 406.07$ & $184.06 \pm 91.87$ \\
\hline Malignant & 19 & $46.57 \pm 15.21$ & $256.46 \pm 126.49^{* *}$ & $1387.7 \pm 378.71^{*}$ & $203.18 \pm 97.65$ \\
\hline
\end{tabular}

$* * *$ Highly significant difference in comparison to control at $(\mathrm{P}<0.001)$

$* *$ Significant difference in comparison to control at $(\mathrm{P}<0.01)$

$*$ Significant difference in comparison to control at $(\mathrm{P}<0.05)$

Circulating immunoglobulins have detected in $75 \%$ of patients with head and neck carcinoma [33]. The major immunoglobulin produced by plasma cell is $\mathrm{IgG}$, makes up to $70-75 \%$ of the total immunoglobulins, and diffuses more readily than other immunoglobulins into the extravascular spaces. Unlike IgA which constitute only $10-15 \%$ of serum immunoglobulins, its unique ability to be selectively transported across mucosal barrier into the lumen of mucosa lined organs, make it important to early warning defense system. The reproducible elevation of sera IgA and IgG of oral tumor patients observed in this study, may be also a result of the natural antibody response to the presence of antigens of oral cancer, or as a defense reaction against increasing tumor load, or may be due to the secretion of immunoglobulin by the tumor itself [33]. Kashmoola[34] on his study on salivary immunoglobulins (IgA, IgG and IgM ) reported an elevation in saliva $\mathrm{IgG}$ and $\operatorname{IgM}$ and a reduction in secretory salivary $\operatorname{IgA}$. He suggested that such increased levels of IgG ad IgM was attributed to their leakage from interstitial fluids through the damaged oral mucosa.

From the results of this study, a conclusion may be achieved, that oral tumor (benign and malignant) affects the sera and salivary protein's composition and concentration as compared with healthy individuals, and might be helped in the diagnosis and prognosis of oral cancer.

\section{References}

1. Lee J.M., Garon E. and Wong D.T. 2009. Salivary Diagnostics, Orthod Craniofac Res. 12:206-211.

2. Kaufman E. and Lamster I.B. 2007. The diagnostic applications of saliva-a review, Crit Rev Oral Biol Med. 13:197-212.

3. Pink R.J., Simek J., Vondrakova E., Faber P. and Michl J. 2009. Saliva as a diagnostic medium. Drug Meta. Disposition Fast Forward 154:103-110

4. Turner R.J. and Sugiya H. 2008. Understanding salivary fluid and protein secretion. Oral Diseases. $8(1): 3-11$ 
5. Miller C.S., King PJr., Langub C., Kryscio J. And Thomas M.V. 2006. Salivary biomarkers of exiting periodontal disease. A crosssectional study. J Am Dent Assoc. 137:322-329.

6. Hofman L.F. 2001. Human saliva as a diagnostic specimen. Rev.J.Nutr. 131:1621-1625

7. Zimmermann B.G. and Wong D.T. 2008. Salivary mRNA targets for cancer diagnostics. Oral Oncol 44(5):425-429

8. Edger W.M. 1992. Saliva: its secretion, composition and functions. Br. Dent. J. 172:305-312.

9. $\mathrm{Hu}$ S., Loo J.A. and Wong D.T. 2007. Human saliva proteome analysis. Ann.N.Y.Acad. Sci. 1098(1):323-329.

10. Amerongen A.V., Ligtenberg A.J. and Veerman E.C. 2007. Implications for diagnostics in the biochemistry and physiology of saliva. Ann.N.Y. Acad. Sci. 1098(1):1-6.

11. Ginzkey C., Kampfinger K., Friehs G. and Kohler C. 2009. Nicotin induces DNA damage in human salivary glands. Toxicol.Lett. 184:1-4.

12. Suzuki H. 2006. Protein, Protein interactions in the mammalian brain. J.Physiol.575:10271-10277.

13. Kantola S., Parikka M. and Jokinen K. 2000. Prognostic factors in tongue cancer-relative importance of demographic, clinical and histopathological factors. Br. J. Cancer 83:614-619.

14. Mavazesh M. 1993. Methods for collecting saliva. Ann.N.Y.Acad.Sci 20:72-77.

15. Hartree E.E. 1972. Determination of protein: A modification of Lowry method that gives a linear photometric response. Anal.Biochem.48:422-427.
16. Doumas B.T. and Watson W.A. Biggs H.G. 1971. Albumin standard and the measurement of albumin with bromocresol green. Clin Chim Acta 31:87-96.

17. Mancini G., Carbonava A.O. and Heremans J.F.1965. Immunochemical quantitative of antigen by single radical immunodiffusion. Immuno Chem. 2:235-254.

18. Neuhoff V.,Arold N., Taub D. and Ehrhard W. 1988. Improved staining of proteins in polyacrylamide gels including isoelectric focusing gell with clear background at nanogram sensitivity using Comassie Brilliant Blue G250 and R-250. Electrophoresis 9:255-262.

19. Leach B.S.,Collawn F.J. and Fish W.W.1980. Behavior of glycopoly- peptides with empirical molecular weight estimation methods. Biochmestry 19:57345741.

20. Joaquim P. 2007. "Applied Statistics using SPSS, Statistica, Matlab and R". $2^{\text {nd }}$ edn., Springer Company USA., 205-211,PP.499451.

21. Grizzle E.W., Adam B.L. and Bigbee W.L.2003. Protein expression profiling for cancer detection. Cancer 19:185-195.

22. Hasan H.R., Dawood R.M. 2010. Study of some hydrolytic enzymes in sera and saliva of patients with oral epithelial tumors.Raf.Jou.Sci 22(2):11-28.

23. Devlin T.M. 2006. Textbook of Biochemistry with clinical correlations. willy-liss, $6^{\text {th }}$., USA.P.86-87.

24. HamadA.W.R. and IbraimM.A, Mohtasib S.I. 2009. Comparative study on saliva proteins in patients of Brain Tumors and healthy individuals. Trends in Med Res 4:16-23. 
25. Sanjay P.R., Halikeri K. And Shivashankara A.R. 2008. Evaluation of salivary sialic acid, total protein and total sugar in oral cancer: a preliminary report. Indian J Dent Res 19(4):288-291.

26. Abe H., Okuno N. and Takeda O.1994. Analysis on heterogeneity of sequamous cell carcinoma antigen by two-dimentional electrophoresis. Electrophoresis 15(7):988-991

27. Smitha C.N., Sweta S. and Basu S.K. 2011. Role of C-reactive protein and periodontal disease in systemic health:A review. J Adv Dent Res 2(1): 1-6.

28. Rizzoli R., Ammon P., Chevalley T. and Bonjour J.P. 2001. Protein intake and breast cancer. Joint Bone Spire 68:383-392.

29. Roche M., Rondeau P., Singh N.R., Tarnus E. and Bourdon E. 2008. The antioxidant properties of serum albumin. FEBS Letts 582:1783-1787.
30. Shpitzer T., Hamzany Y., Bahar G., Feinmesser R. and Savulescu D. 2009. Salivary analysis of oral cancer biomarkers. Br J Cancer 6(7):1194-1198.

31. Miricescu D., Greabu M., Totan A. and Didlescu A. 2011. The antioxidant potential of saliva: clinical significance in oral disease. Therapeutics, pharmacology and clinical toxicology. Xv (2) 139-143.

32. Izutso K., Truelove E.L. and Bleyer W.A. 1981. Whole saliva albumin as an indicator of stomatitis in cancer therapy patients. Cancer 48:1450-1454.

33. Scully C. 1982. Immunologic abnormalities in oral carcinoma and oral keratosis. J Max Fac Surg 113114.

34. Kashmoola M.A., Talabani N.G. and Hamad A.R. 2001. Changes in the composition of saliva in oral cancer patients. Quantitative analysis of immunoglobulins. Iraq Dent $\mathrm{J}$ 27:39-50. 


\section{تقييم البروتينات في مصل و لعاب المرضى المصابين بأورام الفم

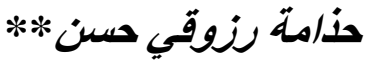 \\ * ت ركزان محمود د/ؤد
* قسم الكيمياء/كلية التربية للبنات/جامعة الموصل ***قم الكيمياء/كلية العلوم/جامعة بغداد التراد

(الخلاصه.

تضمنت المجموعة قبد الدراسة 33 مريضا (ذكور و اناث) مصابين بأورام الفم (الحميدة و الخبيثة)و باعمار

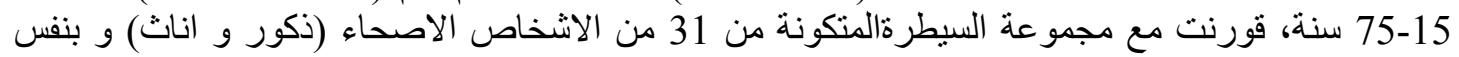

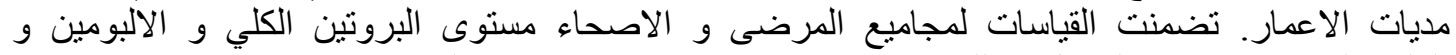

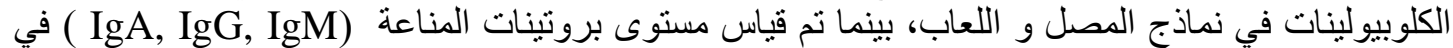

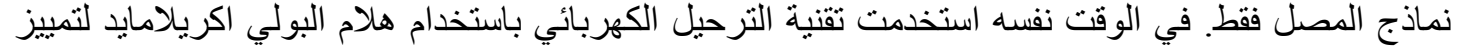

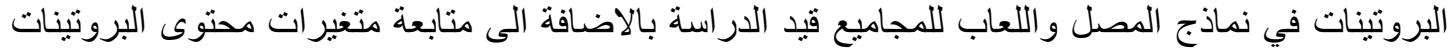

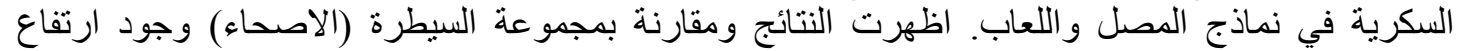

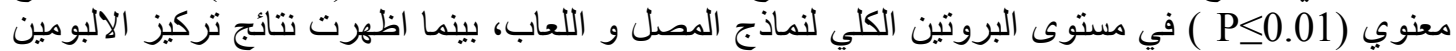

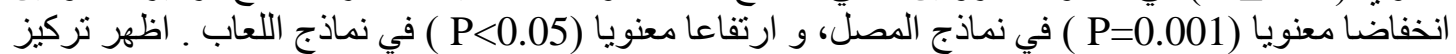

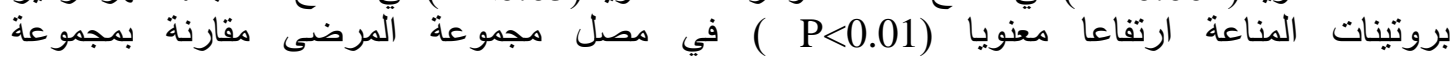
السيطرة(الاصحاء). تهدف هذه الدر اسة الى قياس البروتينات في مصل ولعاب مرضى سرطان الفم و مقارنتها مع مجمو عة السبطرة

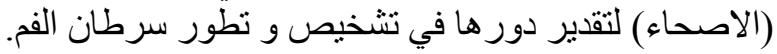

